\title{
HIGH RESOLUTION BIOSTRATIGRAPHIC ANALYSIS OF LATE CARBONIFEROUS- LOWER PERMIAN FOURTH ORDER DEPOSITIONAL SEQUENCES FROM THE NORTH AMERICAN MIDCONTINENT
}

BOARDMAN, Darwin R., II, Dept. of Geology, Oklahoma State University, Stillwater, OK 74078-0451, U.S.A.; WARDLAW*, Bruce R., U.S. Geological Survey, 926A National Center, Reston, VA 22092-0001, U.S.A., NESTELL, Merlynd K., Dept. of Geology, Univ. of Texas at Arlington, Arlington, TX 76019-0049, U.S.A.

Bed by bed lithologic and paleoecologic analysis of Late Carboniferous and Early Permian cyclothemic-scale (Fourth Order 0.1 to $1 \mathrm{my}$ ) and subcyclothemic scale (Fifth Order 0.01 to 0.1 my) depositional sequences from the North American Midcontinent allows identification of major marine flooding surfaces and marine condensed sections that help define parasequence, parasequence set, and systems tract boundaries. Additionally, conodonts recovered from these intervals show significant evolutionary development between many successive fourth order sequences that permits high resolution intrabasinal as well as interbasinal correlation of the high frequency depositional sequences. A summary of conodont faunas of latest Carboniferous and earliest Permian (late Gzhelian-basal Sakmarian) fourth-order depositional sequences are as follows:

The Brownville Sequence has long served as the approximate correlative position of the base of the Permian and contains a unique assemblage of Streptognathodus including $S$. brownvillensis, $S$. n.sp. 1 and $S$. n.sp. 2.

The Falls City Sequence contains a Streptognathodus alius and the continued presence of $S . \mathbf{n}$. sp. 1.

The Foraker Sequence contains Streptognathodus wabaunsensis, S. elongatus, S. farmeri, $S$. conjunctus, and $S$. n.sp. 3, and $S$. n.sp. 4.

The basal Permian Red Eagle Sequence is characterized by Streptognathodus n.sp. 5, S. invaginatus, S. fuchengensis, S. nodulinearis, S. n.sp. 4, S. elongatus, and Sweetognathus expansus.

The Grenola Sequence is characterized by a significant turnover in species of Streptognathodus, including the continued presence of $S$. fuchengensis, $S$. invaginatus, $S$. nodulinearis, $S$. n.sp. 5 and Sweetognathus expansus along with Streptognathodus n.sp. 6, S. n.sp. 7, and S. n.sp. 8.

The Beattie Sequence is characterized by Streptognathodus fusus, $S$. longissimus, $S$. constrictus, S. n.sp. 6, and Sweetognathus expansus.

The Bader sequence is characterized by Streptognathodus postfusus, $S$. constrictus, and by the appearance of Sweetognathus merrilli. The presence of $S w$. merrilli has long been considered to signify the base of the Sakmarian Stage.

The diagnostic, successive conodont faunas identify each of the Fourth Order sequences and allow accurate correlation to successions outside the Midcontinent. 